\title{
The Translation of English Figures of Speech Found in the Novel Temperatures Rising into Indonesian
}

\author{
I Putu Pebri Pranata ${ }^{1 *}$, Sang Ayu Isnu Maharani ${ }^{2}$, I Made Netra $^{3}$ \\ ${ }^{[123]}$ English Department, Faculty of Arts, Udayana University \\ ${ }^{1}$ [pebripranatha@gmail.com], ${ }^{2}$ [isnu.maharani@yahoo.com], ${ }^{3}$ [dektih@yahoo.com] \\ *Corresponding Author
}

\begin{abstract}
This study is entitled The Translation of English Figures of Speech Found in the novel Temperatures Rising into Indonesian. It was formulated two problems; types of figures of speech found in the novel entitled Temperatures Rising and the translation strategies implemented by translator to translate English figures of speech. It is aimed to find the types of figures speech in the novel and analyze the translation strategies implemented by the translator in the translation of the English figures of speech. The data which were used for this study were taken from an English romantic novel entitled Temperatures Rising in 1989 and its translation Hasrat Membara published by PT Gramedia Pustaka Utama in 2104. Documentation method was used in this study by reading attentivelt and doing note-taking. Qualitative method was used to analyze the data. Besides, the result of analysis is explained descriptively. Two theories proposed by Larson were applied in this study. The first theory that mentions the type of figures of speech was used to discuss the first problem. The second theory that explains the translation strategy was used to discuss the second problem. The study showed that there were six types of English figures of speech found in the novel. Based on the second formulated problem in this study, it showed that there were only two strategies implememted by the translator to translate the English figures of speech.
\end{abstract}

Key words: Translation, Figures of Speech, Novel.

\begin{abstract}
Abstrak
Penelitian yang berjudul The Translation of English Figures of Speech Found in the novel Temperatures Rising into Indonesian mengangkat dua pokok masalah yakni; tipe majas yang ditemukan dalam novel berjudul Temperatures Rising and strategi terjemahan yang diimplementasikan oleh penerjemah untuk menerjemahkan majas Bahasa Inggris. Penelitian ini bertujuan untuk menemukan tipe-tipe majas yang muncul dalam novel dan menganalisa strategi terjemahan yang diimplementasikan oleh penerjemah dalam terjemahan majas Bahasa Inggris. Data-data yang digunakan di dalam penelitian ini diambil dari sebuah novel Bahasa Inggris berjudul Temperatures Rising pada tahun 1989 dan terjemahaannya di dalam Bahasa Indonesia berjudul Hasrat Membara yang diterbitkan oleh PT Gramedia Pustaka Utama pada tahun 2014. Metode dokumentasi digunakan di dalam penelitian ini, yakni dengan teknik membaca dengan teliti dan melakukan pencatatan. Metode Kualitatif digunakan untuk menganalisa data. Dua teori yang diusulkan oleh Larson diterapkan di penelitian ini. Teori pertama yang menyebutkan tipe-tipe majas digunakan untuk mendiskusikan masalah pertama. Teori kedua yang menjelaskan strategi terjemahan digunakan untuk mendiskusikan masalah kedua. Penelitian ini menunjukkan bahwa ada enam tipe majas
\end{abstract}


Bahasa Inggris yang ditemukan dalam novel. Berdasarkan masalah kedua dalam penelitian ini, menunjukkan bahwa ada dua strategi terjemahan yang diimplementasikan oleh penerjemah dalam menerjemahkan majas Bahasa Inggris.

Kata kunci: Terjemahan, Majas, Novel

\section{Background of the Study}

Exploring and discussing about a certain literary work and its translation has been regarded as an interesting issue. A novel is a literary work that describes fictional characters and events in the form of sequential story and even portrays human life. The fact that nowadays novel is considered as the most-read literary work among people especially for the adolescents.

The language style in a novel must be one factor that makes the novel become distinctive and interested for the readers. Figurative language is said to be the language style that gives a special effect of a sentence found in a novel. Figurative language is often represented by the use of figures of speech.

A figure of speech is sort of an expression or way of stating and saying one certain thing in another way. In other words, a figure of speech is used to express an idea, thought, or image with words or phrases which carry meanings beyond their literal ones.

Translating the figures of speech needs a certain strategy to be implemented by the translator. It is expectedly done in order to be acceptable and understandable by the TL reader. There will be no confusion occuring among the readers. As the main purpose of translation is to preserve the meaning, the translator is expected to do a consideration in implementing the strategy to translate some cultural terms like figures of speech in order to make the translation as natural as possible without removing or even hindering the SL intended meaning. The English novel Temperatures Rising and its translation Hasrat Membara was interesting to be analyzed for its figures of speech and their translation strategies. It was selected to be analyzed in terms of types of the figures of speech and the way they were implemented in the TL through translation strategies

\section{Problems of the Study}

a) What types of figures of speech were found in the novel entitled Temperatures Rising?

b) What translation strategies were implemented by the translator to translate the English figures of speech into Hasrat Membara?

\section{Aims of the Study}

a) To classify the types of the figures of speech found in the novel entitled Temperatures Rising.

b) To analyze the translation strategies implemented to translate the English Figures of Speech into Hasrat Membara.

\section{Research Method}

Research method explains the procedure in doing the research. Concerning to the topic of this study, the aspects involved are; Data source, Method and Technique of Collecting data, Method and Technique of Analyzing data and Method and Technique of Presenting analysis.

\subsection{Data Source}

The data of this study were taken from two novels; Temperatures Rising is considered as one of the famous English romantic novels written by Sandra Brown in 1989 and published by Bantam on February $1^{\text {st }} 1993$. The romantic novel Temperatures Rising has its Indonesian 
version entitled Hasrat Membara which was selected and used as target language (TL) novel in this study. This novel was translated by Rahmani Astuti and published by PT. Gramedia Pustaka Utama anggota IKAPI, Jakarta in 2014.

\subsection{Method and Technique of Collecting Data}

The method that was used to collect the required data was the documentation method. This method was done by doing some techniques, namely; (1) The technique of reading attentively and accurately, and (2) The note-taking technique. The technique of reading attentively was done with the focus of words or phrases that contain the figures of speech in a sentence of a text in Temperatures Rising as Source Language novel. Afterwards, the identified figures of speech were marked, highlighted and then noted by applying the note-taking technique. Note-taking was done to make the identification process become easier.

\subsection{Method and Technique of Analyzing Data}

The descriptive qualitative method was applied to give an actual explanation descriptively. The collected data of this study were analyzed according to these followings steps: (1) Identifying followed with classifying figures of speech found into each type of figures of speech based on Larson's theory (1998). The theory mentioned that type of figures of speech are; Metonymy, Synecdoche, Idiom, Euphemism, Hyperbole, Metaphor and Simile. (2) Analysing the figures of speech from Temperatures Rising as SL novel and their translations in Hasrat Membara in order to find out the translation strategies implemented by the translator. It was done by applying the theory proposed by Larson (1998) about translation strategy in dealing with figures of speech.

\subsection{Method and Technique of Presenting Analysis}

The formal and informal methods were applied in presenting the analysis of the first and second problems, since the analysis was presented in words and table. The analysis was presented by several steps; (1) The collected data were classified into types of figures of speech, namely; Metonymy, Synecdoche, Idiom, Euphemism, Hyperbole, Metaphor and Simile. The analysis of the figures of speech was explained descriptively. (2) The figures of speech were distinguished based on the implemented strategies. In each strategy, the figure of speech and its translation were placed in a table. The explanation of the translation strategy in each figure of speech was also added and explained descriptively.

\section{Result and Discussion}

\subsection{Types of Figures of Speech}

\subsubsection{Metonymy}

Still, I know she's eager to have her fiancé back in the States." (Temperatures Rising, 1993:4).

Literally, State is a nation or territory considered as an organized political community under one government (Meriam Webster Dictionary). It can be seen from the data, States was used as a place where Jennifer was eager to have her fiancé back. This word serves a secondary meaning instead of its literal meaning which refers to a nation or territory. It is considered interesting to be explored because the author did not take the direct word which can directly inform to the readers that America is the place where Jennifer wanted to have her fiancé back. Actually, the author referred the word States as a country which specifically refers to America. Therefore, 
it is recognized as a metonymy because the word States used by the author associates to a country which is America.

\subsubsection{Idiom}

He yanked the camera from her, tossed it onto the ground, and did a cannonball into the pool, taking her with him. (Temperatures Rising, 1993:126)

The phrase did a cannonball has nothing to do with a cannonball, in fact it refers to how a cannonball moves. The cannonball moves by rolling itself. The use of did a cannonball to context of the sentence is to describe how Scout survived himself and Chantal from the furious expulsion of Voix de Tonnerre (Volcano) by rolling his body (did a cannonball) into the pool and taking her with him. If the words are interpreted literally, they will have no sense and do not fit to the context. Thus, they are supposed to be in a group to form an idiom of figure of speech and express the beyond meaning from their literal.

\subsubsection{Euphemism}

I want you. Sleep with me, Chantal. Please." (Temperatures Rising, 1993:115)

The words sleep with me literally means an offer to ask to sleep together. In fact, it can be seen from the context, the words sleep with me have a beyond meaning than asking someone to sleep with. Actually, these words express an offer to have sex with someone. Moreover, the author used the words sleep with me in order to describe that Scout was asking Chantal to have sex with him. If an offer like have a sex is uttered directly to someone, she or he will get offended of being asked to have sex, this usually happens toward girls or women when they are being asked to have sex with someone. The use of words sleep with me is to avoid the sense of offensive and the directness of a statement instead of using words have a sex to the sentence because it relates to an action of doing sexual activity which is usually done by a loverIt is used in terms of decreasing the feeling of being offended caused by offensive or too direct words such as have sex which can be replaced by sleep with me. Accordingly, it is called a euphemism of figure of speech because the use of the expression sleep with me has avoided the offensiveness of words.

\subsubsection{Hyperbole}

"Of course, I sweated off about ten pounds." (Temperatures Rising, 1993:112)

Pound or Pound-mass is a unit of mass used in the imperial, United States customary and other systems of measurement. It is known that one pound can be defined as 0,5 kilogram. It means that Scout produced 5 kilograms of sweat. It can be seen from the data that there is a phrase ten pounds used by the author in order to inform the reader how drenched his sweat was which covered his body that Scout got after having an adventure to the top of the hill with a purpose to meet George duPont (Chantal's father). I sweated off about ten pounds is an exaggeration because this sentence describes when Scout was getting much sweat that drenched his body. This hyperbole intends to describe that Scout's body was full of sweat like he was wet after taking a shower.

\subsubsection{Metaphor}

"It seems you're the hero of the day. (Temperatures Rising, 1993:128)

Basically, hero is a person who is admired or idealized for courage, outstanding achievements, or noble qualities. From the data, Chantal 
expressed her compliment toward Scout by considering him as the hero of the day. Scout successfully made the bridge for the people in Parish Island and he was greeted cheerfully by the people with a traditional ceremony. He was admired for his hard-working and willingness in helping the people in Parris Island to build a new bridge which had been expected for years. What had been done by Scout also describes a hero's characteristic, for his courage and outstanding achievements to build bridge.

\subsubsection{Simile}

Pieces of wadded-up littered the floor like snowballs. (Temperatures Rising, 1993:63)

Literally, snowball is a round mass of snow pressed or rolled together (Meriam Webster Dictionary). The author used snowballs to describe the sketches or papers done by Scout. It can be proven from the story that Scout was making some sketches which would be used as his plan in making the new bridge for the people in Parrish Island. Those sketches he made were spread on the floor, and Chantal got shocked of them. Therefore, the spreading papers or sketches were described by the word snowballs to express a simile of figure of speech.

\subsection{Translation Strategy}

\subsubsection{Translating a figure of speech into non-figure of speech.}

\begin{tabular}{|c|c|c|}
\hline No. & $\begin{array}{c}\text { Source } \\
\text { Language }\end{array}$ & $\begin{array}{c}\text { Target } \\
\text { Language }\end{array}$ \\
\hline 1. & $\begin{array}{l}\text { "So bad I'm } \\
\text { almost teary- } \\
\text { eyed." } \\
\text { (Temperatures } \\
\text { Rising, } \\
\text { 1993:28) }\end{array}$ & $\begin{array}{l}\text { "Ingin sekali, } \\
\text { sampai nyaris } \\
\text { aku menangis." } \\
\text { (Hasrat } \\
\text { Membara, } \\
2014: 49)\end{array}$ \\
\hline
\end{tabular}

The figure of speech teary-eyed is an example of Idiom. This figure of speech was translated into menangis in TL.
Literally, teary can be translated into berkaca-kaca and eyed can be translated bermata, so if they are translated literally, it will bermata berkaca-kaca which has unclear meaning and does not fit to the SL meaning. However, from those literal meanings, the translator could make a consideration in translating the idiom of figure of speech teary-eyed into menangis which is more naturally accepted. By having a look at SL and TL, it can be concluded that the SL figure of speech had been translated into nonfigure of speech in TL. In other words, the figure of speech teary-eyed had been translated plainly in Target Language. Since the meaning of SL is cry, this strategy was implemented to make the translation become naturally accepted and TL reader can comprehend what idiom teary-eyed is. The sense in TL that can be naturally accepted is the act of expressing distress or pain by letting out the tears from eyes known as cry in which it is known as menangis in TL.

\subsubsection{Translating a figure of speech into figure of speech.}

\begin{tabular}{|c|c|c|}
\hline No. & $\begin{array}{c}\text { Source } \\
\text { Language }\end{array}$ & $\begin{array}{c}\text { Target } \\
\text { Language }\end{array}$ \\
\hline 1. & $\begin{array}{l}\text { He ran through } \\
\text { the house like } \\
\text { madman. } \\
\text { (Temperatures } \\
\text { Rising, } \\
\text { 1993:147) }\end{array}$ & $\begin{array}{l}\text { Scout berlari ke } \\
\text { seluruh penjuru } \\
\text { rumah seperti } \\
\text { orang sinting. } \\
\text { (Hasrat } \\
\text { Membara, } \\
2014: 248 \text { ) }\end{array}$ \\
\hline
\end{tabular}

The figure of speech like madman is an example of Simile. This figure of speech was translated into seperti orang sinting in TL. In English, a madman is known as a man who has such mental illness. As a Target Language, Indonesia also has this kind of thing known as orang sinting. Therefore, it is clearly seen that the translator translated like madman into seperti orang sinting by implementing the third strategy that is 
translating the figure of speech into figure of speech in TL. It means that a metaphor in SL has been translated into a metaphor in TL. The TL text is still in form of Simile that compares two things directly and obviously making a correlation using certain words like a word seperti. By having a look at SL and TL, there is no meaning which was reduced from implementing this strategy. Both SL and TL state the same meaning that Scout is like madman.

\section{Conclusion}

Firstly, this study is aimed to find the types of figures of speech in the novel entitled Temperatures Rising written by Sandra Brown in 1989. Based on the analysis in the previous chapter, there are six types of figures of speech found in the novel entitled Temperatures Rising, namely; Metonymy, Idiom, Euphemism, Hyperbole, Metaphor, and Simile. There is only one type of figures of speech that does not exist in the novel that is called as Synecdoche. From those six types of figures of speech, Simile, Metaphor, and Idiom, seem having higher number of findings or dominantly found.

Secondly, this study is aimed to analyze the translation strategy used by the translator in translating the SL figures of speech found in Temperatures Rising into its Indonesian translation in Hasrat Membara. Larson proposed three strategies in dealing with translating figures of speech. From those three strategies, there are only two which had been implemented in translating the figures of speech, namely: the first strategy that is translating the figure of speech into non-figure of speech in TL and the third strategy is translating the figure of speech into figure of speech in TL. According to the analysis, it can be concluded that the first strategy was frequently implemented to translate one type of figures of speech, that is, Idiom.
In addition, it was also followed by Metonymy, Euphemism, and also Hyperbole. There also can be concluded that the third strategy was frequently implemented in translating one type of figures of speech, that is, Simile. Besides, it was also followed by Hyperbole and Metaphor.

\section{References}

Astuti, Rahmani. (ed) (2014). Hasrat Membara. PT. Gramedia Pustaka Utama, Jakarta.

Brown, Sandra. (1989). Temperatures Rising. Bantam, U.S.A.

Larson, Mildred L. (1998). MeaningBased Translation "A Guide to Cross-Language Equivalence”. New York: University Press of America.

Merriam Webster Inc. (1995). Merriam Webster's Encyclopedia of Literature. Merriam Webster p.415. ISBN 9780877790426. 